\title{
ALEKSANDRA WIŚNIEWSKA
}

\section{Z dalekiej Galicji do Wiednia. Siegfried Lipiner - bibliotekarz niepospolity}

Streszczenie. Celem artykułu jest przybliżenie sylwetki Siegfrieda Lipinera (1876-1911) - poety, admiratora Nietzschego, przyjaciela i doradcy Mahlera, tłumacza dzieł Mickiewicza, a także świetnego bibliotekarza.

Urodzony w Jarosławiu Siegfried Lipiner w 1875 roku przeniósł się do Wiednia, gdzie z wyróżnieniem zdał maturę i skończył studia na Wydziale Filozoficznym. $\mathrm{Na}$ lata gimnazjalne przypadają jego pierwsze próby poetyckie. Już jako student Lipiner skupił wokół siebie grono przyjaciół, w tym Gustava Mahlera, na którego twórczość jako najbliższy przyjaciel i doradca wywarł znaczny wpływ. Opublikowany w 1876 roku epos Der entfesselte Prometheus wzbudził duże uznanie Nietzschego i zainteresował Wagnera. Późniejsze utwory Lipinera nie spotkały się już z tak pozytywnym odzewem.

W 1881 roku dzięki rekomendacji dr. Franciszka Smolki, przewodniczącego Izby Posłów, otrzymał pracę w Bibliotece Parlamentu Wiedeńskiego, w której przepracował z zaangażowaniem 30 lat. Do jego zasług należy zwiększenie dotacji dla biblioteki oraz pozyskanie nowych współpracowników naukowych, w tym Karla Rennera późniejszego kanclerza i prezydenta Austrii. Dzięki współpracy z nimi możliwe było opracowanie nowych katalogów systematycznych, w tym katalogu kartkowego, który był w użyciu do 1995 roku. Starania Lipinera doprowadziły do uzyskania dodatkowej powierzchni bibliotecznej (obecnej czytelni). Po 30 latach jego urzędowania biblioteka parlamentu zaliczana była do najlepszych.

Oprócz pracy bibliotecznej Lipiner dalej tworzył, a także podnosił swoje kwalifikacje. W 1894 uzyskał doktorat na podstawie dysertacji Homunculus, eine Studie über Faust und die Philosophie Goethes. Oprócz tego pracował za namową hr. Karola Lanckorońskiego nad przekładami dzieł Adama Mickiewicza: Pana Tadeusza oraz Dziadów - wydane w 1883 i 1887 roku do dziś uważane są za wybitne.

SŁowA KLuczowe: Siegfried Lipiner (1856-1911), Adam Mickiewicz - przekłady, Gustav Mahler, Biblioteka Parlamentu Wiedeńskiego. 
„Umarł nieznajomy. Radca rządowy i dyrektor biblioteki to nie ów Siegfried Lipiner, który przed trzydziestu laty zabłysnął na firmanencie ducha kreśląc świetlisty szlak" ${ }^{1}$ - tymi słowy rozpoczyna się notatka pośmiertna poświęcona jednemu z bardziej nietuzinkowych bibliotekarzy, zarazem poecie i filozofowi, który z dalekiej Galicji trafił do wiedeńskiego parlamentu.

Skromny nekrolog zamieszczony przez wdowę, Clementine Lipiner, nie odzwierciedlał niepospolitych zdolności Lipinera, które mogły mu wróżyć, zwłaszcza u progu życia, świetlaną karierę. Mimo swego niewątpliwego talentu odszedł jako poeta zapomniany. Dziś jednak, po przeszło 100 latach, nadal jest obecny w opracowaniach literackich i nie tylko.

\section{Źródła}

Celem niniejszego artykułu jest przybliżenie sylwetki Siegfrieda Lipinera - poety, admiratora Nietzschego, przyjaciela i doradcy Mahlera, jako tłumacza dzieł Mickiewicza, a także świetnego bibliotekarza. Jest to tym bardziej potrzebne, że $w$ polskojęzycznych źródłach znajduje się niewiele informacji na jego temat. Kilkanaście wersów poświęca mu Roman Taborski w kompendium Polacy $w$ Wiedniu ${ }^{2}$, na nim opiera swą notkę o Lipinerze Andrzej Niewiadowski, autor Austrii po polsku³. Wzmianka o Lipinerze jako tłumaczu pojawia się w Literaturze polskiej w przekładach 1990-2000 pod redakcją Danuty Bilikiewicz-Blanc ${ }^{4}$ czy też w pozycji Literatura polska: przewodnik encyklopedyczny ${ }^{5}$, natomiast żadna z encyklopedii PWN, ani Nowa encyklopedia PWN w ośmiu tomach, ani nawet trzydziestojednotomowa Wielka Encyklopedia PWN nie wspomina o nim słowem. Spośród obcojęzycznych źródeł wymienić należy ciekawy i obszerny szkic Roberta A. Kanna poświęcony Lipinerowi jako „przedstawicielowi polsko-austriackoniemieckiej syntezy kulturalnej”, opublikowany w „Zeszytach Naukowych Uniwersytetu Jagiellońskiego" w języku niemieckim6. Zawiera on jednak niewiele informacji na temat okresu pracy Lipinera

1 J. Bach, Siegfried Lipiner, "Arbeiter Zeitung” 1912, nr 10, s. 1.

2 R. Taborski, Polacy w Wiedniu, Wrocław 1992.

3 A. Niewiadowski, Austria po polsku, Warszawa 2009.

4 Literatura polska w przekładach 1990-2000, red. D. Bilikiewicz-Blanc, Warszawa 2000.

5 Literatura polska: przewodnik encyklopedyczny, t. 1, red. C. Hernas, Warszawa 1984.

6 R.A. Kann, Siegfried Lipiner (1856-1911) als Vertreter einer polnisch-deutschösterreichischen kulturellen Synthese, "Zeszyty Naukowe Uniwersytetu Jagiellońskiego. Prace Historyczne" 1980, z. 68, s. 99-107. 
w bibliotece. Najbogatsze źródło w tym zakresie stanowi opracowanie Nur was sich ändert bleibt! Die österreichiche Parlamentsbibliothek im Wandel der Zeit 1869-2002 autorstwa Christiana Pecha7. Wśród omówionych tam kolejnych dyrektorów biblioteki parlamentu Lipiner - jako najdłużej sprawujący tę funkcję, a także ze względu na swe zasługi - zajmuje poczesne miejsce. Z kolei twórczości literackiej Lipinera poświęcono trzy dysertacje powstałe na Uniwersytecie Wiedeńskim ${ }^{8}$. Jego nazwisko pojawia się w kontekście filozoficzno-literackich koncepcji końca XIX wie$\mathrm{ku}, \mathrm{w}$ niemieckojęzycznych opracowaniach na temat historii literatury, w pozycjach na temat Mahlera, Nietzschego, Wagnera i innych znanych osobistości, z którymi Lipiner się przyjaźnił lub był w kontakcie. Pokaźne noty biograficzne zawarto m.in. w publikacjach: Österreichisches biographisches Lexikon 1815-1950, Neue deutsche Biographie oraz Lexikon deutsch-jüdischer Autoren'. W Polskim słowniku biograficznym natomiast jego nazwisko nie figuruje.

\section{Początki pod znakiem Nietzschego i Wagnera}

Punktem wyjścia może być to, co sam Siegfried Lipiner napisał o sobie w curriculum vitae, którego oryginał przechowuje wiedeńskie Archiwum Uniwersyteckie, w ramach dokumentacji złożonej w związku z doktoratem na temat Homunculus, eine Studie über Faust und die Philosophie Goethes w roku 1894:

Siegfried Lipiner, wyznania ewangelickiego, urodzony w Jarosławiu w Galicji, do niższych klas gimnazjalnych uczęszczał w Tarnowie, do wyższych we Wiedniu, tam też zdał w 1875 r. z wyróżnieniem egzamin dojrzałości; następnie podjął studia na Uniwersytecie Wiedeńskim na Wydziale Filozoficznym w latach 1875-1878, z wyjątkiem semestru letniego 1876, który spędził na Uniwersytecie w Lipsku. Studiował nauki przyrodnicze, literaturę i historię, ale przede wszystkim filozofię. Po zaliczeniu trzech lat studiów poświęcił się głównie

7 C. Pech, Nur was sich ändert bleibt! Die österreichische Parlamentsbibliothek im Wandel der Zeit 1869-2002, Wien 2002.

8 G. Brezina, Siegfried Lipiner 1856-1911: eine Monographie, Wien 1925; I. Schein, Die Gedanken- und Ideenwelt Siegfried Lipiners, Wien 1936; H. von Hartungen, Der Dichter Siegfried Lipiner (1856-1911), [s.1.] 1935.

9 Österreichisches biographisches Lexikon 1815-1950, red. E. Obermayer-Marnach, t. 5, Wien 1993, s. 231; Neue deutsche Biographie, t. 14, red. H. Körner, Berlin 1985, s. 642-643; Lexikon deutsch-jüdischer Autoren, red. R. Heuer, t. 16, München 2008, s. $72-74$. 
naukom z zakresu ekonomii państwa, statystyki itp.; w 1881 r. powołany został przez k.k. ministra spraw wewnętrznych na stanowisko bibliotekarza austriackiego Reichsratu, na którym do dziś pracuje. Opublikował, oprócz mniejszych prac, szczególnie na polu filozofii, również szereg większych prób poetyckich i niemieckie opracowanie głównych dzieł polskiego poety Mickiewicza Pan Tadeusz i Dziady ${ }^{10}$.

Ten własnoręcznie napisany życiorys, skromny i skrótowy, w niewielkim stopniu odzwierciedla bogatą osobowość i talent Lipinera. Urodził się 24 października 1856 roku, w rodzinie żydowskiej, w 1871 roku przeniósł się do Wiednia. Już jako uczeń Leopoldstädtergymnasium uchodził za wyjątkowo zdolnego, w gimnazjum uczęszczał nawet na wykłady uniwersyteckie, w ostatnich klasach gimnazjalnych powstały jego pierwsze próby literackie - epos Echo, tragedia historyczna Arnold von Brescia, a także część utworu dramatycznego Der entfesselte Prometheus. Ten ostatni, opublikowany podczas studiów na Uniwersytecie Wiedeńskim, w 1876 roku, przesłany do Nietzschego i Wagnera, zwrócił ich życzliwą uwagę. Nietzsche przyjął utwór wręcz z entuzjazmem, a młodego poetę określił jako "geniusza"11. Lipiner nie bez powodu akurat do Nietzschego się zwrócił (za pośrednictwem jego przyjaciela, prof. Erwina Rhodego), bowiem oprócz swych uniwersyteckich przedmiotów czytywał z zapałem dzieła Schopenhauera, Wagnera i Nietzschego i zapisał się do stowarzyszenia studentów, które je pilnie studiowało (Leseverein der deutschen Studenten Wiens). Paul-Laurent Assoun określa go nawet jako najbardziej zaangażowanego w ",apostolat” Nietzschego ${ }^{12}$. Życzliwa reakcja Nietzschego sprawiła, że nawiązali kontakt listowny, ale dość szybko ich relacja się ochłodziła. Nietzsche wkrótce odżegnał się od tej znajomości. Podobnie dzieje się w wypadku Wagnera. Słysząc od Malvidy von Meysenbug i Nietzschego o talencie młodego poety, zaprosił go latem 1878 roku na parę dni do Bayreuth, jednak ich znajomość również się urwała. Najnowszy utwór Lipinera, Renatus, nie znalazł w oczach Wagnera ani jego żony aprobaty, a krytyczne uwagi poety pod adresem

${ }^{10}$ Oryginał dostępny w Archiwum Uniwersytetu Wiedeńskiego; tłumaczenie z języka niemieckiego tego i następnych cytatów - o ile nie wskazano inaczej - A.W.

${ }^{11}$ List Friedricha Nietzschego do Erwina Rhode z 28.08.1871, w: F. Nietzsche, Gesammelte Briefe, Berlin 1900-1909, t. 2, Schuster und Loeffler, s. 538: „Wenn der Dichter nicht ein veritables Genie ist, so weiß ich nicht mehr was eines ist: alles ist wunderbar, und mir ist, als ob ich meinem erhöhten und verhimmlischen Selbst darin begegnete. Ich beuge mich tief vor einem, der so etwas in sich erleben und herausstellen kann" - cyt. za: R.A. Kann, op.cit.

12 P.L. Assoun, Freud and Nietzsche, London 2002, s. XXII. 
Schopenhauera, jak i polityczne dyskusje zdają się obu różnić. Nie doszło też do wydania dwóch tekstów nadesłanych przez Lipinera do nowo założonego pisma „Bayreuther Blätter”, z którym autor zamierzał nawiązać współpracę, zwłaszcza że jego sytuacja finansowa była mocno niestabilna ${ }^{13}$. Niemniej Lipiner do końca życia pozostawał pod wpływem Wagnera ${ }^{14}$.

Zdaniem Roberta A. Kanna nieudane kontakty mogły wynikać z niechęci lub nieumiejętności Lipinera, by poddawać się kaprysom czy też dostosowywać się do wrażliwości wielkich artystów. A może zanadto starał się narzucić swój punkt widzenia i rady, tak w każdym razie wynika z poirytowanego tonu listu Nietzschego do przyjaciela, Reinharda von Seydlitza, w którym Nietzsche zarzuca Lipinerowi nadmierne wtrącanie się do jego spraw, wręcz bezwstydną chęć dysponowania jego życiem, wobec czego woli trzymać się od niego z daleka ${ }^{15}$. Z kolei Marion Schmaus ${ }^{16}$ przytaczajak to określa - anegdotę, która miała zaważyć na zerwaniu przez Nietzschego kontaktów z Lipinerem. Z odnalezionych w Goethe- und Schiller-Archiv w Weimarze listów Lipinera do Heinricha Köselitza - przyjaciela i współpracownika Nietzschego - wynika, że Nietzsche został zapisany za pośrednictwem Lipinera na kurację do dr. Josefa Breuera w Wiedniu (współtwórcy psychoanalizy wraz z Freudem). Co więcej, Lipiner uczynił to samowolnie i sam wyasygnował środki. Gdy w końcu dowiedział się o tym Nietzsche, z oburzeniem odrzucił propozycję, a na kurację - za pomocą zimnych zabiegów wodnych - pojechał do Baden-Baden.

Jak widać, Lipiner miał oryginalne pomysły. Freud, notabene, był kolegą Lipinera ze studiów, zakładali nawet razem - wspólnie z dwoma dalszymi znajomymi, Emanuelem Löwy i Josephem Panethem - pierwsze czasopismo Freuda, które ukazywało się do 1875 roku najprawdopodobniej tylko w ściśle prywatnym kręgu ${ }^{17}$.

${ }^{13}$ A. Venturelli, Kunst, Wissenschaft und Geschichte bei Nietzsche: quellenkritische Untersuchungen, Berlin 2003, s. 272.

14 R.A. Kann, op.cit., s. 102.

15 Por.: „Gerne hätte ich von Thnen etwas über Lipiners Eindruck auf Sie gehört. Bei mir hat er sich eigentlich durch seine wiederholten Versuche aus der Ferne her über mein Leben zu disponiren und durch Rath und That in dasselbe einzugreifen unmöglich gemacht. So etwas verabscheue ich: keiner meiner ältesten Freunde würde wagen, mir solche dreiste Dinge zu proponiren. Mangel an Scham - das ist es. Von so Einem muß ich ganz ferne sein, dann gelingt es mir ganz gut, selbst ein Freund zu werden - aber in partibus" - cyt. za: A. Venturelli, op.cit., s. 269.

${ }^{16}$ M. Schmaus, Psychosomatik: literarische, philosophische und medizinische Geschichten zur Entstehung eines Diskurses (1778-1936), Tübingen 2009, s. 417.

17 P.L. Assoun, op.cit., s. XXII. 
Lipiner był obdarzony wielką wrażliwością i darem wymowy, a także rozległą wiedzą. Zachowało się świadectwo uczestnika jednego z wykładów w Towarzystwie Czytelniczym Studentów Niemieckich w Wiedniu (Leseverein der deutschen Studenten Wiens), określające go jako młodego i niepozornego mężczyznę, który „dzięki sile swej sugestywnej wymowy umiał przykuć uwagę wszystkich słuchających"18. Podobne wrażenie wywarł Lipiner podczas semestru spędzonego w Lipsku w 1876 roku, gdzie podczas uroczystości w Towarzystwie Literackim (Literarisches Verein Leipzig) wygłosił godzinną przemowę na temat Schillera ${ }^{19}$ - podziw wzbudziły wówczas jego jasność myśli, płynność wymowy i dobór środków wyrazu.

\section{Twórczość literacka}

Już w pierwszej publikacji, Der entfesselte Prometheus, w której widać wpływy Schopenhauera, Nietzschego oraz Wagnera, pojawia się motyw przewodni całej twórczości Lipinera - motyw wybawienia, religijnego wyzwolenia człowieka ${ }^{20}$. W styczniu 1878 roku Lipiner wygłosił wykład w Towarzystwie Czytelniczym Studentów Niemieckich w Wiedniu zatytułowany Über die Elemente einer Erneuerung religiöser Ideen der Gegenwart. Kolejna publikacja to wspomniany epos Renatus (1878), dedykowany Malvidzie von Meysenbug, przyjaciółce Nietzschego i Wagnera, następnie zbiór liryki Buch der Freude (1880). Tragedia Der neue Don Juan (1880), w której uwodziciel przedstawiony zostaje jako ofiara kobiet, wystawiona zostanie dopiero po śmierci autora. Od grudnia 1880 do października 1881 roku pracował jako dziennikarz dla „Deutsche Zeitung Wien”, publikując felietony na tematy związane z literatura, sztuka, z kwestiami religijnymi i społecznymi ${ }^{21}$. W tym czasie powstało też libretto do wystawionej w 1886 roku opery Karla Goldmarka Merlin. Również w 1881 roku Lipiner rozpoczął pracę w bibliotece parlamentu, spowalniając znacznie prace pisarskie. Niemniej w 1883 roku wydał fragment utworu poetyckiego Bruder Rausch, opublikowany w zbiorze Deutsches Dichterbuch aus Österreich pod redakcją Karla Emila Franzosa, a w 1894 roku uzyskał doktorat na podstawie wspomnianej wyżej, wysoko ocenionej pracy Homunculus, eine Studie über Faust und die Philosophie Goethes. Jednocześnie pracował nad szeroko zakrojoną trylogią Chrystus dotyczącą

\footnotetext{
${ }^{18}$ H. von Hartungen, op.cit., s. 2.

${ }^{19}$ Ibidem, s. 4.

${ }^{20}$ R.A. Kann, op.cit., s. 104.

${ }^{21}$ H. von Hartungen, op.cit., s. 8.
} 
idei wybawienia - przez cierpienie, czystą miłość, w chrześcijańskim znaczeniu - problemów, które zaprzątały go od młodości. Zresztą Lipiner da im wyraz, przechodząc w 1891 roku na protestantyzm. Natomiast dzieło, któremu poświęcił swe dojrzałe lata, wielekroć przerabiane, pozostało niedokończone. Opublikowana została jedynie - w 1813 roku, już po śmierci Lipinera, w opracowaniu jego przyjaciela Paula Natorpa - tragedia Adam, napisana w 1898 roku, pomyślana jako prolog do powstającej trylogii. W manuskrypcie pozostała pierwsza niepełna wersja Marii Magdaleny oraz fragmenty Judasza Iskarioty, brak informacji o trzeciej części mającej nosić tytuł Paweł w Rzymie. W 1900 roku spod pióra Lipinera wyszedł jeszcze przekład poetycki Fedry Eurypidesa zatytułowany Hippolytos, wydany również w 1913 roku przez Paula Natorpa.

Podsumowując twórczość Lipinera, literaturoznawcy stwierdzają zgodnie, że jego późniejsze dzieła epickie i dramatyczne nie powtórzyły już sukcesu pierwszego eposu z 1876 roku $^{22}$. Prądy epoki - naturalizm, a później impresjonizm - nie sprzyjały tematyce niełatwych do zrozumienia symbolicznych utworów Lipinera, na przełomie wieków nie budziły większego zainteresowania idee wybawienia człowieka i problematyka międzywyznaniowej religijnej wolności ${ }^{23}$. Może zabrakło też twórczej wyobraźni? Hartmut von Hartungen w podsumowaniu swej dysertacji wyraża uznanie dla pięknego, dźwięcznego języka, szerokiej wiedzy i zdolności poetyckich Lipinera, ale zarazem zwraca uwagę na brak tej siły twórczej, która by go wyniosła na wyżyny, na bardziej naśladowczą niż twórczą naturę pisarza ${ }^{24}$.

Z drugiej strony sam autor zdawał się nie tak bardzo o to dbać. Zdaniem jednego z jego najbliższych przyjaciół, dyrygenta i kompozytora Bruno Waltera był przede wszystkim improwizatorem, potrzebował słuchacza, bezpośredniego odbiorcy swych myśli, kogoś, kto by go zarazem rozumiał i podziwiał ${ }^{25}$. Walter, porównując Mahlera z Lipinerem, wysuwa

${ }^{22}$ W. Kriegleder, Eine kurze Geschichte der Literatur in Österreich, Wien 2011, s. 244.

${ }^{23}$ R.A. Kann, op.cit., s. 105.

${ }^{24}$ H. von Hartungen, op.cit., s. 80, por.: „Die Dichtungen Lipiners zeichnen behutsame Pflege einer schönen klangvollen Sprache und feines Gefühl für die Musikalität des Wortes aus. Wir verspüren bei dem Dichter ein reiches Wissen, ein Aufwärtsringen und ein nicht gewöhnliches Dicht- und Denkvermögen, aber doch zum Schluß ein Versagen in dem Moment, wo es den letzten entscheidenden Aufschwung und den letzten künstlerischen Schritt gilt. Zur eigentlichen Höhe gelangt der Dichter nicht. Ihm fehlt dazu die Kraft der künstlerischen Gestaltung, und sein ganzes Wesen ist dafür zu sehr machahmender und zu wenig schöpferischer Natur".

25 B. Walter, Thema und Variationen: Erinnerungen und Gedanken, Stockholm 1947, s. 218: „Und er dichtete und dachte, aber er schrieb wenig, denn er war von Natur 
hipotezę odnośnie do skromnego dorobku Lipinera: podkreślając stałość i autentyczność jego przyjaźni, zwraca uwagę, że jego „niepraktycznej” naturze brakowało egocentrycznej postawy, niezbędnej do większych twórczych dokonań ${ }^{26}$.

\section{Mahler i inni}

Bardzo istotne $\mathrm{w}$ życiu Lipinera były jego rozliczne przyjaźnie, miał wyjątkową zdolność gromadzenia wokół siebie ludzi. Jakub Forst-Battaglia tak o tym pisał:

Lipiner jako człowiek musiał na wrażliwe umysły wywierać głębokie wrażenie, skoro do kręgu jego admiratorów należały tak znaczące i tak różne pod względem duchowej orientacji osobowości jak Nietzsche, Gustav Mahler, psycholog Gustav Fechner, socjaliści Viktor Adler i Engelbert Pernerstorfer, katolicko-konserwatywny neoromantyk Richard von Kralik i dyrygent Bruno Walter ${ }^{27}$.

Rzeczywiście, już w czasach studenckich Lipiner skupił wokół siebie grono utalentowanych młodych ludzi, z których część należała do wspomnianego stowarzyszenia Leseverein der deutschen Studenten Wiens byli wśród nich m.in. Viktor Adler, późniejszy polityk, założyciel Socjaldemokratycznej Partii Austrii i jej organu "Arbeiter-Zeitung"; Engelbert Pernerstorfer, podobnie jak Adler jeden z przywódców socjaldemokracji, zarazem nauczyciel, wydawca, polityk; jego szwagier Heinrich Braun, socjaldemokratyczny publicysta i polityk. To oni połączeni wspólnym podziwem dla filozofii Nietzschego wystosowali w październiku 1887 roku

ein Improvisator und geschaffen, sich in freier Rede, in persönlicher Mitteilung zu verstromen. Hatte er zur Zeit der Peripatetiker in Griechenland gelebt, er wäre einer von denen geworden, die im Auf- und Abwandeln mit Schülern redend lernten. In einer Epoche, da der Dichter hauptsächlich durch die Druckerpresse zur Mitwelt spricht, war er eine unzeitgemäße Gestalt. Auch bedurfte er, der in menschlichen Beziehungen aufging, das Andern, des Zuhörenden, Verstehenden, Lernbegierigen, Begeisterungsfähigen, um sich an dessen Fragen und Verstehen zu entflammen".

${ }^{26}$ Ibidem, s. 228: „Daß aber Lipiner, der gleichfalls schöpferische Geist, sich so viel beständiger im Menschlich-Freundschaftlichen auslebte, zeigt, woran es ihm zum höchsten Typus des Schaffenden fehlte, nämlich an jener egozentrischen Verfassung, die die charakterliche Grundlage der großen produktiven Leistung ist. Es kommt vor, wenn auch nicht häufig, dass der Genius der Menschheit in so unpraktischen Kombinationen wie dem Lipinerschen Wesen seine Interessen vernachlässigt, wobei die unmittelbare Mitwelt gewinnt, was der Nachwelt entgeht".

27 J. Forst-Battaglia, Polnisches Wien, Wien 1983, s. 79. 
list do filozofa z okazji jego urodzin ${ }^{28}$. Do grona bliskich przyjaciół należał też poznany w 1879 roku w Strasburgu Paul Natorp, niemiecki filozof, autor kilku artykułów o poecie bardzo - może nawet nazbyt - pochlebnie oceniających jego twórczość ${ }^{29}$, a także wydawca części jego dzieł oraz jeden $z$ opiekunów jego literackiej spuścizny. Friedrich Eckstein, przyjaciel Freuda, wspomina z kolei, że również pisarz Hermann Bahr, późniejszy prezydent Austrii Michael Hainisch czy też pierwszy czechosłowacki prezydent Tomáš G. Masaryk należeli do grona bliskich znajomych Lipinera $^{30}$.

Niewątpliwie najbardziej znaczący w tym gronie był Gustav Mahler, który o cztery lata starszego Lipinera uważał za najbliższego przyjaciela i doradcę. Przyjaźń z Mahlerem nadała Lipinerowi większy rozgłos niż jego publikacje. Wspominają o niej niemal wszystkie pozycje poświęcone Mahlerowi, tak istotny był wpływ Lipinera na kompozytora w sferze literackiej, estetycznej, religijnej. Aldo Venturelli tak o niej pisze: „Może ta przyjaźń właśnie czyni życie galicyjskiego poety godnym uwagi po roku 1881, kiedy to zdaje się, iż niemal zupełnie zniknął ze sceny kulturalnej, po to aby się całkiem poświęcić spokojnej pracy bibliotekarza (sic!) Parlamentu" ${ }^{\prime 3}$.

Mahler bardzo szanował rady Lipinera, wysoko oceniał też jego twórczość, którą uważał za bardzo pokrewną muzyce ${ }^{32}$. Jeden z utworów poetyckich Lipinera ze zbioru Buch der Freude, zatytułowany Genesis, zainspirował go przy tworzeniu III Symfonii - z jednej strony kompozytor posłużył się jego „poetycką kosmologią”, z drugiej nadał jej nowy sens $^{33}$. W tej samej III Symfonii według cytowanego już Richtera widać także wpływ Lipinera na odbiór Nietzschego przez Mahlera. Z kolei w VIII Symfonii oprócz bezpośredniej inspiracji Faustem Goethego krytycy dopatrują się wyraźnego wpływu wymiany poglądów z Lipinerem, dla którego dzieło Goethego - przedmiot jego dysertacji - odgrywało

\footnotetext{
${ }^{28}$ A. Venturelli, op.cit., s. 257.

${ }^{29}$ H. von Hartungen, op.cit., s. 7.

${ }^{30}$ M. Csáky, Das Gedächnis der Städte, Wien 2010, s. 162.
}

${ }^{31}$ A. Venturelli, op.cit., s. 277: „Vielleicht ist diese Freundschaft das, was das Leben des galizischen Dichters nach 1881 erwähnenswert macht, da Lipiner nahezu aus dem Kulturleben zu verschwinden scheint, um sich ganz der ruhigen Tätigkeit eines Bibliothekars des Reichsrates zu widmen".

${ }^{32}$ H. Lengauer, Siegfried Lipiner: Biographie im Zeichen des Prometheus, w: Die österreichische Literatur im Profil von der Jahrhundertwende bis zur Gegenwart (1880-1980), red. H. Zeman, t. 2, Graz 1989, s. 1238.

${ }^{33}$ C. Floros, Gustav Mahler, Visionary and Despot. Portrait of A Personality, Frankfurt am Main 2012, s. 154. 
ważną rolę w artystycznym i filozoficznym programie duchowej odnowy społecznej3.

Dzięki Lipinerowi również duch naszego wieszcza Adama Mickiewicza zagościł w muzyce Mahlera. Pierwsza część II Symfonii miała początkowo stanowić samodzielny poemat symfoniczny i nosiła tytuł Todtenfeier - napisana została na podstawie IV części Dziadów Mickiewicza, które Mahler poznał dzięki tłumaczeniu Lipinera, wydanemu w Lipsku w 1887 roku $^{35}$.

\section{Lipiner jako tłumacz}

Bardzo możliwe, że zasługi Lipinera jako tłumacza przewyższają jego dokonania literackie. Przywołany już Bruno Walter we wspomnieniach pisał, że nawet gdyby własne utwory Lipinera przepadły wskutek katastrof wojennych, to „siła jego języka przetrwa w mistrzowskich przekładach na język niemiecki dzieł wielkiego polskiego poety Adama Mickiewicza Dziady i Pan Tadeusz" ${ }^{\prime \prime 3}$. Przystąpił do nich za namową hr. Karola Lanckorońskiego, który miał także - według Waltera - przyczynić się do uzyskania przez Lipinera posady bibliotekarza. Warto w tym miejscu poświęcić kilka słów postaci zasłużonej dla kultury polskiej i austriackiej.

Karol Antoni hr. Lanckoroński herbu Zadora, polski historyk, członek Polskiej Akademii Umiejętności, kawaler maltański, dziedziczny członek austriackiej Izby Panów, od 1914 roku wielki szambelan dworu cesarskiego - to postać niezwykle ciekawa, o szerokich zainteresowaniach naukowych, które skupiały się głównie na sztuce, konserwacji zabytków i archeologii śródziemnomorskiej. Prowadził m.in. prace konserwatorskie starochrześcijańskiej bazyliki romańskiej w Akwilei, za co Akwileja nadała mu w 1906 roku honorowe obywatelstwo. Zasłużył się też w Wiedniu należał do tych, którzy zapobiegli projektowanemu usunięciu słynnego romańskiego portalu nad głównym wejściem do katedry św. Szczepana, przebudowie zabytkowej wieży Minoritenkirche oraz zabudowaniu perspektywicznego widoku na kościół św. Karola. Był pionierem ochrony zabytków i nowoczesnej służby konserwatorskiej w Polsce. W katedrze

${ }^{34}$ C.A. Kita, Myth, Metaphysics and Cosmic Drama: The Legacy of Faust in Lipiner's Hippolytos and Mahler's Eight Symphony, "Monatshefte University of Wisconsin Press" 2013, t. 105, s. 543-564; C. Niekerk, Vienna Around 1900 and the Crisis of Public Art: On Text and Music in Klimt, Mahler, and Schnitzler, "Neophilologus” 2011, t. 95, s. 103.

${ }^{35}$ C. Floros, op.cit., s. 142.

${ }^{36}$ B. Walter, op.cit., s. 218. 
na Wawelu ufundował sarkofag Królowej Jadwigi i płytę nagrobkową Zbigniewa Oleśnickiego. Z powodzeniem działał na rzecz usunięcia z Wawelu wojsk austriackich. W 1918 roku brał udział w pracach Głównego Urzędu Likwidacyjnego w Warszawie, zajmując się sprawą zwrotu Polsce zbiorów i archiwów wywiezionych podczas zaborów przez Austrię. Całe życie spędził w Austrii, ale o Polsce nie zapominał, należał do Koła Polskiego w parlamencie austriackim, dzieci wychował w polskim duchu. Po upadku monarchii austro-węgierskiej Karol Lanckoroński przyjął wraz z rodziną obywatelstwo polskie. Wspierał rozliczne sprawy polskie w Wiedniu. Przewodniczył przykładowo komitetowi odnowienia otwartego w 1898 roku polskiego kościoła na Rennwegu. Należał do Towarzystwa Biblioteki Polskiej w Wiedniu. Nieprzypadkowo więc dzięki jego inicjatywie i mecenatowi doszło do wydania przez Siegfrieda Lipinera przekładów na niemiecki Pana Tadeusza i Dziadów.

Dobór tłumacza, jak się okazało, był bardzo trafny, do dziś uważa się przekład Lipinera za nadzwyczaj udany. Pan Tadeusz (Herr Thaddäus oder der letzte Einritt in Litauen) został przetłumaczony aleksandrynem, natomiast Dziady (Totenfeier) białym wierszem. Robert Kann ${ }^{37}$ podkreśla, że już zaraz po ukazaniu się translacje uznane zostały za mistrzowskie, jak wynika z korespondencji Overbecka i Nietzschego na temat Pana Tadeusza, wydanego w 1882 roku. Także obecnie przyznaje się, że to one utorowały drogę Mickiewiczowi do kręgów kultury niemieckojęzycznej, a zasługi Lipinera na tym polu są tym większe, że język Mickiewicza nie był łatwy, sprawiał trudności nawet późniejszym pokoleniom polskich czytelników.

Do dziś wznawiane są niektóre tłumaczenia Lipinera lub ich fragmenty, figurują one przykładowo w wyborze poezji i prozy Mickiewicza w opracowaniu Karla Dedeciusa z 1994 roku bądź w antologii Polnische Romantik wydanej w 1998 roku $^{38}$.

Lipiner opatrzył każdy z przekładów, którym poświęcił ponad 20 lat pracy, interesującym biograficznym wstępem zawierającym również odniesienie do pracy tłumacza. We wstępie do Dziadów przykładowo tak pisze na temat klasycznego problemu - wierności tłumaczenia:

Wobec mojego autora nie zachowywałem się jak niewolnik - być może jednak nie dość swobodnie, by być zupełnie wiernym. Prawdziwa sztuka przekładu nie powinna przez nic dać się związać, jak tylko poprzez zamiar, by oddziaływanie

37 R.A. Kann, op.cit., s. 105-107.

38 Dichtung und Prosa: ein Lesebuch, oprac. K. Dedecius, Frankfurt am Main 1994; Polnische Romantik: ein literarisches Lesebuch, red. H.P. Hoelscher-Obermaier, Frankfurt am Main 1998. 
przekładu było dokładnie to samo, co oryginału; obojętnie za pomocą jakich to będzie środków ${ }^{39}$.

Pana Tadeusza i Dziady poprzedziło wydanie tłumaczenia wierszy Mickiewicza w 1879 roku. Do skutku nie doszła natomiast publikacja jeszcze jednego przekładu Lipinera - utworu Zygmunta Krasińskiego, z którym Lipinera wiązało także powinowactwo duchowe. Jego Ułamek naśladowany z glosy św. Teresy (Fragment nach der Glosse der heiligen Therese) pozostał $\mathrm{w}$ manuskrypcie.

Uznanie dla poetyckich dokonań Lipinera w przekładzie z jednoczesnym przeciwstawieniem ich jego twórczości oryginalnej przewija się również w cytowanej na początku notatce Bacha. Autor pisze, że właśnie w tłumaczeniu Lipiner jest naprawdę poetą ${ }^{40}$. Najwyższą jakość tych przekładów uznawała nawet Alma Mahler, z którą o 20 lat starszy Gustav Mahler ożenił się w 1902 roku i która od samego początku uważała Lipinera za swego wroga, doprowadziła też jeśli nie do całkowitego rozstania, to jednak do znacznego wieloletniego ochłodzenia ich przyjacielskich relacji.

\section{"Spokojna praca bibliotekarza" i jej efekty}

W pracy tłumacza pomogła Lipinerowi zapewne owa „spokojna praca bibliotekarza”, jak wspomniano wyżej zgodnie z powszechnie panującym - tak przed stuleciem jak dziś - stereotypem. Jednocześnie dał się od początku poznać jako bardzo sumienny i odpowiedzialny bibliotekarz, dzięki któremu owa młoda jeszcze wówczas placówka - działająca zaledwie od 12 lat - rozwinęła się i okrzepła. Młody był zresztą sam parlamentaryzm - dopiero w 1861 roku na mocy tzw. patentu lutowego cesarz Franciszek Józef powołał dwuizbowy parlament: Radę Państwa (Reichsrat) złożoną z Izby Panów i Izby Posłów.

Młody był sam Lipiner obejmujący to dość eksponowane stanowisko miał dopiero 24 lata i duży zapas entuzjazmu. W Bibliotece Wiedeńskiej

${ }^{39}$ Wprowadzenie, w: A. Mickiewicz, Todtenfeier (Dziady), Leipzig 1887, s. XXXII: „Ich habe mich zu meinem Autor nich sklawisch verhalten - und doch vielleicht nicht frei genug, um ganz treu zu sein. Wahre Übersetzungskunst darf sich ja durch nichts binden lassen, als durch die Absicht genau die Wirkung des Originals zu erzielen; mit welchen Mitteln das erreicht wird, ist gleichgültig”.

${ }^{40}$ J. Bach, op.cit., s. 2: „In der Nachdichtung ist Lipiner das, was ihm in der selbstständigen Dichtung versagt schien: ein Dichter. Als Mittler der Kulturträger zweier Nationen, hat er seine höchste wirkungsreichste Tat vollbracht". 
w ratuszu (Wienbibliothek) zachował się jego list do jednego z przyjaciół, Moritza Neckera, z 24 sierpnia 1881 roku, w którym prosi o wyszukanie adresów Rudolfa i Piotra Krzyżanowskich oraz Mahlera: „Właśnie mianowano mnie na stanowisko bibliotekarza, 4 września mam ślub (na który dostaniesz jeszcze zaproszenie) i rozpływam się ze szczęścia. Poza tym mam tyle do zrobienia, że chyba zwariuję"41.

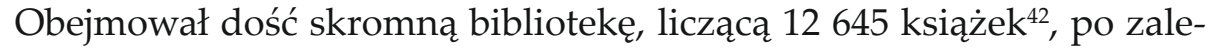
dwie trzech poprzednikach. Pierwszy bibliotekarz, Franz J. Koch, zmarł po roku, wówczas całe zbiory mieściły się w 17 skrzyniach: „8 Kästen aus

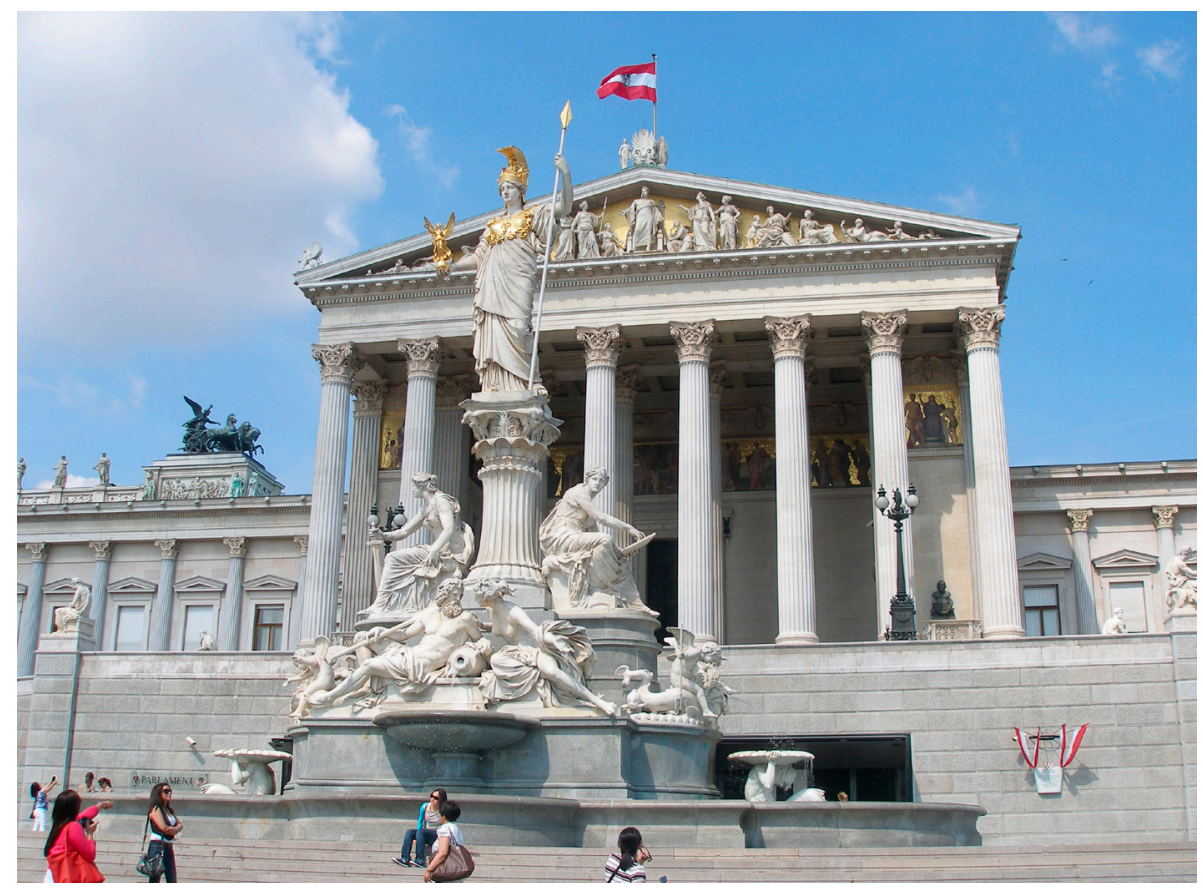

Il. 1. Gmach parlamentu wiedeńskiego Źródło: zbiory autorki.

41 „Ich bin bereits zum Bibl. ernannt, habe am 4. September Hochzeit (zu der du noch eingeladen werden wirst) und schwimme in Glück. Thabe übrigens so viel zu thun, dass ich toll werde" - pisownia według oryginału: rękopis w zbiorach Wienbibliothek, ID-Nr. LQH0136529. Moritz Necker (1857-1915, urodzony we Lwowie, dziennikarz i krytyk literacki, autor m.in. opracowań na temat F. Grillparzera, M. von Ebner-Eschenbach, J. Nestroya; ślub, o którym mowa w liście: z Niną Hoffmann, z którą Lipiner się rozstanie; po raz drugi ożeni się w 1891 roku z Klementine Spiegler (informacja na podstawie H. von Hartungen, op.cit., s. 9).

42 Te i następne informacje dotyczące biblioteki parlamentu, o ile nie podano inaczej, pochodzą z: C. Pech, op.cit., s. 13-52. 


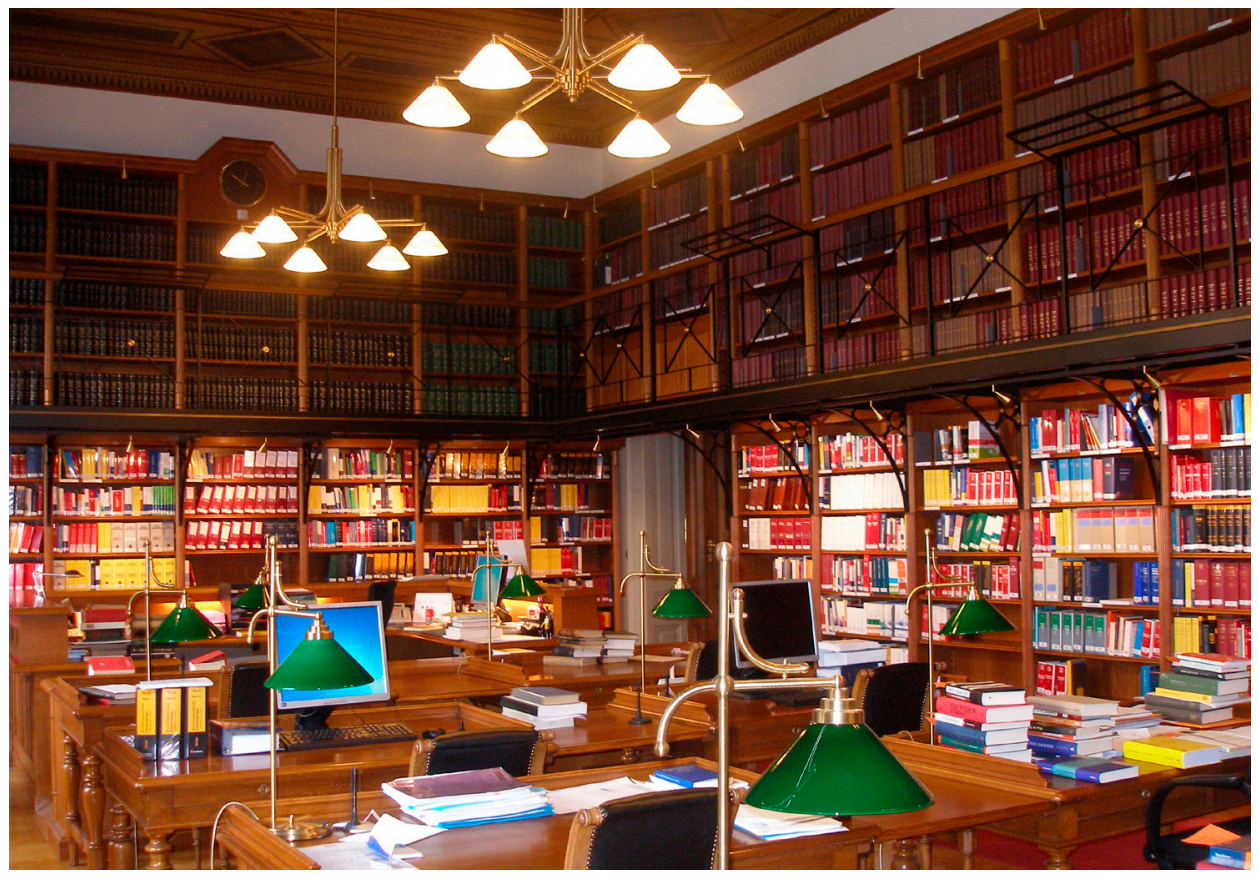

Il. 2. Czytelnia Biblioteki Parlamentu Wiedeńskiego Źródło: zbiory autorki.

hartem Holze und 9 Kästen aus weichem Holze". Było to około 6000 tomów (sam bibliotekarz nie wiedział ile), a lichy budżet starczał na zakup około 120 książek rocznie.

Drugi bibliotekarz - od 1870 do 1876 roku - dr Johann Vincenz Goehlert był wcześniej urzędnikiem w Ministerstwie Spraw Wewnętrznych, troszczył się głównie o opracowanie regulaminu (Bibliotheks-Dienst-Instruktion), według którego zakup książek był możliwy tylko na podstawie pisemnego zamówienia lub zgody prezydium którejś z izb. Mimo tych utrudnień Goehlert starał się aktywnie o wzbogacenie księgozbioru, przejmując m.in. zbiory rozwiązanego Centralnego Archiwum Ustawodawstwa i Statystyki. Za jego czasów też wyszedł drukiem pierwszy katalog (w 1871 roku), nie zawierał on jednak sygnatur, których w książkach wciąż jeszcze brakowało, stanowił skrzyżowanie czy raczej pomieszanie haseł autorskich i rzeczowych. Rok później ukazał się kolejny katalog, tym razem rzeczowy, który wskazywał zarazem miejsce przechowywania książek.

Następca Goehlerta, Johann Freiherr von Päumann, skrytykował porządki poprzednika, niepełność katalogu i brak kontroli wypożyczeń. Gdy przejmował bibliotekę, sporządził protokół zdawczo-odbiorczy 
i stwierdził brak 72 książek. Był emerytowanym tymczasowym szefem (z powodu braku odpowiedniego kandydata), ale przepracował pięć lat (1876-1881), co przyniosło mu dodatek 800 florenów do emerytury - budżet biblioteki wynosił wówczas 1500 florenów. Päumann nadał książkom sygnatury, równolegle zaprowadził cztery katalogi (alfabetyczny na fiszkach, dwa drukowane i rejestr nabytków). Sam publikował pod pseudonimem Hans Max komedie, krotochwile i operetki. Interesował się również polską literaturą: przetłumaczył i wydał komedię Pierwej Mama (Zuvor die Mama) Józefa Korzeniowskiego (1797-1863)43.

W 1881 roku Päumann zachorował i wystąpił o urlop. Wkrótce potem ponownie przeniesiono go na emeryturę. Nastąpił kilkumiesięczny okres przejściowy, w którym biblioteką - raz lepiej, raz gorzej - zajmował się Kanzleirat Kupka ${ }^{44}$. Po nim przejął ją na 30 lat Lipiner.

Posadę Lipiner uzyskał dzięki rekomendacji dr. Franciszka Smolki, przewodniczącego Izby Posłów i jednego z najwybitniejszych działaczy Klubu Polskiego ${ }^{45}$. Było to niezwykłe ze względu i na wiek Lipinera, i na pochodzenie (z żydowskiej rodziny). Dał się jednak poznać jako bardzo zdolny młody człowiek i miał już za sobą pierwsze próby poetyckie. Smolka tak uzasadniał tę kandydaturę w liście z 28 stycznia 1881 roku do premiera Eduarda hr. Taaffe: „Lipiner to nie tylko świetnie wykształcony i rozumny człowiek, ale też obeznany z literaturą wszystkich epok, a przy tym również i w życiu prywatnym cieszy się nieposzlakowaną opinią"46.

Po 30 latach jego urzędowania biblioteka parlamentu zaliczana była do najlepszych w swojej kategorii. Paul Natorp, wydawca ostatnich dzieł Lipinera, tak to wyraził we wstępie do Adama: „Biblioteka Parlamentu Wiedeńskiego, którą kierował przez trzydzieści lat, w ogromnej mierze jemu zawdzięcza, że uznana została przez fachowców w tej dziedzinie za jedną z najlepiej urządzonych na świecie" ${ }^{\prime 4}$. Z kolei jego przyjaciel poseł Engelbert Pernerstorfer napisze w nekrologu, że Lipiner oddał swą uniwersalność, wszechstronność na służbę bibliotece i uważał za swój obowiązek, by wszystkim, którzy pragnęli skorzystać ze zbiorów, służyć w charakterze dobrego przewodnika. Nie tylko doradzał, gdzie można

${ }^{43}$ J.F. von Päumann (pseud. Hans Max), Zuvor die Mama! Lustspiel in 1 Aufzug. Frei nach dem Polnischen des Józef Korzeniowski, Wien 1861.

${ }^{44}$ C. Pech, op.cit., s. 22: „In einer Übergangsphase versah «Kanzleirat Kupka recht und schlecht die Obliegenheiten des Bibliothekars»".

${ }^{45} \mathrm{O}$ wstawiennictwie hr. Lanckorońskiego pisał B. Walter, op.cit.

${ }^{46}$ Cyt. za: R.A. Kann, op.cit., s. 103.

47 P. Natorp, Vorwort, w: S. Lipiner, Adam. Ein Vorspiel, Stuttgart 1913, s. 5, cyt. za: C. Pech, op.cit., s. 28. 
znaleźć coś sensownego na dany temat z zakresu prawa, ale i sam na ogół dość wiele wiedział, często więcej od znającego się na rzeczy interesanta. Jak zwykle jednak trafiały się też odmienne opinie.

Według Michaela Hainischa, prezydenta Austrii w latach 1920-1928 (założyciela m.in. bibliotek ludowych), Lipiner „co prawda bibliotekę na nowo urządził i uporządkował, ale o swoją pracę niewiele się troszczył. Przez wiele miesięcy przebywał na urlopie i cały dzień przyjmował gości, a wśród odwiedzających go mocno reprezentowana była piękna płeć" 48 .

Niemniej podczas urzędowania udało się Lipinerowi znacznie podnieść wysokość dotacji dla biblioteki - z początkowych 1500 florenów w 1881 roku po pięciu latach uzyskał 2000 florenów, a od 1887 do 1895 roku nawet 3500 florenów. Umiał przekonać parlamentarzystów! Argumentował, że wielokrotnie większa jest dotacja dla biblioteki niemieckiego Reichstagu i dowodził, jak wielka jest już biblioteka przy węgierskim parlamencie. Zadanie nie było jednak proste, Lipiner wnioskował w 1885 roku o 5000 florenów, a uzyskał 2000, pisał wielostronicowe uzasadnienia rzeczy i dziś jakże oczywistych:

O ile biblioteka ma choć $\mathrm{w}$ jakiejś mierze godnie spełniać swe zadanie, nie można pozostać przy dotychczas przyznawanych nieznacznych środkach. $\mathrm{Na}$ pierwszy rzut oka ten zbiór książek wydaje się zaledwie jakimś czysto fachowym księgozbiorem i mogłoby się wydawać, że wystarczy poprzestać na zakupie zbiorów ustaw zagranicznych i najważniejszych dzieł z zakresu nauk politycznych. Nawet gdyby tak było, to i tak obecna dotacja, a nawet znacznie wyższa od niej, by nie wystarczyła ${ }^{49}$.

Również jego pensja i pozycja wzrosły, co zbiegło się z uzyskaniem doktoratu w 1894 roku - z początkowych 1500 florenów (pensji równej ówczesnemu budżetowi biblioteki) do 2200, do czego doszedł też tytuł radcy rządowego (Regierungsrat).

Kolejny sukces to zwiększenie personelu - odpowiednio w 1893 i 1896 roku - o dwóch współpracowników naukowych. Byli to dr Ladislaus Merklas (późniejszy dyrektor po śmierci Lipinera, pierwszy pracownik naukowy zatrudniony w bibliotece) oraz dr Karl Renner, prawnik, a także znany polityk, późniejszy prezydent Austrii.

Ciekawa jest relacja zawarta w pamiętnikach Karla Rennera na temat okoliczności jego zatrudnienia, wskazująca zarazem, jak bardzo Lipinerowi zależało na wysokich kwalifikacjach pracowników i jak starannie

\footnotetext{
${ }^{48}$ C. Pech, op.cit., s. 28.

49 Ibidem, s. 30.
} 
ich dobierał. Celem wyłonienia odpowiedniego kandydata zwrócił się do dziekana Wydziału Prawa Uniwersytetu Wiedeńskiego prof. Philippovicha z prośbą o wskazanie młodego człowieka o szerokiej wiedzy prawno-ekonomicznej, a jednocześnie chętnego do pracy. Zaznaczył od razu, że „kariery się w tym zawodzie nie da zrobić”, ale gdyby ów młody człowiek miał ochotę i zdolności, umożliwi mu pracę naukową. Dziekan polecił Karla Rennera. Renner zaopatrzony w list polecający od dziekana stawił się na spotkanie o godzinę spóźniony. Gdy przyszedł, od Lipinera wychodził akurat inny kandydat, dr Karl Neißer. Te decydujące chwile tak sam opisuje:

Teraz Pan przychodzi? Decyzje już w zasadzie zapadly. Lipiner dłuższą chwilę mi się przyglądał, po czym rzekł. Mimo to proszę wejść! Pozostałem u niego do godziny trzeciej, odpowiadając na jego liczne błyskawicznie rzucane pytania ze wszystkich dziedzin nauk prawno-ekonomicznych, musiałem mu też przedstawić moja sytuację osobistą i zaprezentować próbkę odręcznego pisma w dwóch wersjach: szybkiej i kaligraficznej. W końcu wyjaśnił mi: Neißer, co prawda, ma już moja zgode, ale Pan mi bardziej pasuje; on jest filozofem, Pan jest prawnikiem; jest Pan młodszy i znacznie szybszy. Tak jak sprawy się teraz maja, moge Pana zatrudnić jedynie, jeżeli uda mi się najpierw znaleźć dla dr Neißera, który z różnych stron ma lepsze referencje, inne miejsce zatrudnienia ${ }^{50}$.

Rzeczywiście udało się go umieścić w archiwum parlamentu, a Renner, po niespełna miesiącu, 1 grudnia 1895 roku rozpoczął pomyślnie pracę $\mathrm{w}$ bibliotece, mając wyznaczone godziny pracy: od 9 do $12 \mathrm{i}$ od 14 do 17. Nie zawiódł też pokładanych w nim nadziei, już po roku uzyskał stopień doktorski i pilnie pracował nad powierzonymi mu zadaniami. Dzięki niemu i dr. Merklasowi Lipiner mógł energiczniej pracować nad katalogami.

Pierwszy nowy katalog za jego czasów wyszedł drukiem w 1884 roku, po przeprowadzce do nowej siedziby: podzielony na 20 dziedzin, z indeksem rzeczowym na końcu; po trzech latach na życzenie użytkowników biblioteki dodrukowano alfabetyczny indeks autorów. W kolejnych latach - 1885, 1887, 1890 - wychodziły tomy uzupełniające. W 1893 roku Lipiner uzasadniał potrzebę zatrudnienia współpracownika (Ladislausa Merklasa) koniecznością wprowadzenia nowego katalogu w miejsce dotychczasowego - przestarzałego i niewygodnego w użyciu wobec dużej liczby nabytków.

${ }^{50}$ K. Renner, An der Wende zweier Zeiten. Lebenserinnerungen, Wien 1946, s. 290. Cyt. za: C. Pech, op.cit., s. 33. 
Dzięki nowym współpracownikom w 1896 roku wyszedł następny, liczący 480 stron, katalog systematyczny według tzw. pruskich instrukcji. Całość księgozbioru ujęto $\mathrm{w}$ jednym alfabetycznym porządku, ujmując zarówno autorów, jak i hasła rzeczowe, pozostawiając co drugą stronę pustą na uzupełnienia (ostatnie pochodzą z 1975 roku). Katalog powstał $\mathrm{w}$ dwóch wersjach $-\mathrm{w}$ jednym tomie oraz w dwóch (A-L, M-Z).

Jednocześnie w 1896 roku zaprowadzono systematyczny katalog kartkowy, który uzupełniano aż do 1995 roku. Podobny wzór kart katalogowych przedstawiał prezydium Izby Posłów już poprzednik Lipinera, Päumann, ale trudno obecnie stwierdzić, czy jego karty wykorzystano w nowo powstającym katalogu, który do dziś nosi nazwę „Katalog Rennera”. Katalog obejmował 667 dziedzin. Wpływ i pracę Karla Rennera szczególnie widać w obrębie działów wiedzy bliskich jego socjaldemokratycznym zapatrywaniom, takich jak socjalizm, komunizm czy kwestia społeczna.

Dziś oczywiście wszystko jest zeskanowane, a zwiedzającym pokazuje się stare kartki katalogowe z odręcznym pismem Karla Rennera. Renner pracował w bibliotece do 1907 roku, kiedy to urlopował się, by móc działać jako poseł. Praca w bibliotece wykluczała aktywne zaangażowanie polityczne, miała bowiem służyć wszystkim jednakowo, niezależnie od zapatrywań. Jeszcze w 1909 roku mianowano go „Bibliotheksdirektor 2. Classe" - "dyrektorem 2. klasy”, ale do biblioteki nie wrócif, a nawet jako czytelnik nie dopilnowywał terminu zwrotu książek. Był ministrem spraw zagranicznych, dwukrotnie kanclerzem, a w 1945 roku prezydentem Austrii. Nic więc dziwnego, że sam prezydent Austrii Heinz Fischer napisał wprowadzenie do historii biblioteki parlamentu autorstwa Christiana Pecha.

Za czasów Lipinera - dwa lata od rozpoczęcia jego urzędowania - nastąpiła przeprowadzka parlamentu do nowego, okazałego gmachu przy Ringu, pobudowanego w latach 1883-1884 według projektu Duńczyka Theophila Hansena, tego samego, który zaprojektował w Wiedniu budynek Musikverein, wspaniałą salę koncertową, skąd transmitowane są słynne koncerty noworoczne.

Wkrótce jednak - jak to w bibliotekach bywa - znów brakowało miejsca na książki. W 1888 roku zamówione zostały nowe regały, ale wskutek kiepskiego stanu finansów wykonano je z miękkiego drewna i pomalowano na dębowy kolor. Również stelaże wymalowano tylko w widocznych dla oka miejscach. Te regały służą jeszcze do dziś. Brakowało też przestrzeni, jej powiększenie jednak nie było łatwym zadaniem. Lipiner wystarał się w końcu o nowe pomieszczenia, choć trwało to osiem lat. W liście z 5 lipca 1888 roku Lipiner tak się zwracał w tej sprawie do przewodniczącego izby poselskiej: 
Ponieważ księgozbiór Biblioteki Parlamentu, szczególnie od czasu zwiększenia dotacji, znacznie się powiększył i z każdym rokiem książek wciąż przybywa, od dawna upragnione poszerzenie powierzchni bibliotecznej stało się $w$ tej chwili palącą potrzebą. Środki, jakie przedsięwziąłem celem jak najlepszego wykorzystania pomieszczeń, są w stanie temu w równie niewielkim stopniu zaradzić, co ewentualne wycofanie tych książek, co do których można przyjąć z jakimś prawdopodobieństwem, że niewiele by się już z nich lub zgoła wcale nie korzystało ${ }^{51}$.

W rezultacie tych starań przydzielono nowe pomieszczenie, w którym wcześniej zbierał się klub poselski Liechtensteinu - dzisiejszą czytelnię, która najprawdopodobniej za czasów Lipinera pełniła podwójną funkcję, służyła również częściowo za magazyn. Niemniej prezydent Izby Posłów mógł 25 października 1895 roku zakomunikować:

Został dzisiaj szanownym Panom przekazany nowy regulamin biblioteczny, zatwierdzony przez prezydium. Być może wiedzą już Panowie, że nastąpiło znaczne udogodnienie w korzystaniu z biblioteki, a to za sprawą adaptacji dużego pomieszczenia na czytelnię, dzięki czemu Panowie Posłowie mogą korzystać ze zbiorów tu na miejscu w bibliotece, w spokojnym pomieszczeniu ${ }^{52}$.

Księgozbiór biblioteki zwiększał się rzeczywiście bardzo dynamiczniepo niespełna dziesięciu latach urzędowania Lipinera był podwojony (25 529 woluminów w końcu 1890 roku), a na koniec stulecia liczył już około 45000 pozycji $^{53}$. Dla porównania - dziś biblioteka posiada ponad 350000 tysięcy książek, do tego 270 tytułów czasopism i bogate zbiory baz danych.

Nie mniej niż na wygodzie czytelnika i przestrzeni dla książek zależało Lipinerowi na dostępności książek i właściwej informacji. Osobiście służył radą i informacją - w duchu dobrze dziś pojętej informacji naukowej.

${ }^{51}$ S. Lipiner, list z 5 lipca 1888 roku (X Session Nr. 1996 Abg.H) - cyt. za: C. Pech, op.cit., s. 49: „Da der Bücherbestand der Reichsrathsbibliotek, namentlich seit der Erhöhung der Dotation, sehr bemerkenswert angewachsen ist und mit jedem Jahre stark zunimmt, ist die seit Langem wünschenswerthe Erweiterung der Bibliotheks-Räumlichkeiten nunmehr zur dringenden Notwendigkeit geworden. Die von mir getroffenen Maßnahmen behufs möglichster Raumnützung vermögen ebenso wenig wesentliche Abhilfe zu schaffen, wie es eine etwaige Ausscheidung jener Bücher vermöchte, von denen mit einiger Wahrscheinlichkeit angenommen werden kann, dass sie wenig oder gar nicht mehr benützt werden dürften".

52 Stenograficzny zapis protokołu z posiedzenia Izby Posłów (XI Sesja, posiedzenie nr 422, 25.10.1895) - cyt. za: C. Pech, op.cit., s. 51.

${ }^{53}$ Ibidem, s. 45. 
W zbiorach rękopisów Austriackiej Biblioteki Narodowej zachował się list Lipinera do prof. Franza von Miklosicha, znanego slawisty i językoznawcy. Przesyłając mu książkę Schönberg's Handbuch, informuje go zarazem, że większość pozycji zawartych w załączonej bibliografii znajdzie u niego w bibliotece, a zapraszając, zaznacza, że można go zastać codziennie między 10 a 14 (wbrew przytoczonym wyżej enuncjacjom Michaela Hainischa!). Zapewnia przy tym: „byłbym wówczas w stanie po krótkim omówieniu problemu zwrócić Panu uwagę na tę czy inną pozycję, która może się Panu szczególnie przydać. Schönberga mogę czy też raczej wolno mi wypożyczyć tylko na bardzo krótki czas: tego typu podręczniki i kompendia muszą być w bibliotece na miejscu do wglądu" ${ }^{\prime 4}$.

Sporym problemem w czasach Lipinera był wielonarodowościowy charakter parlamentu - istnej wieży Babel. Posłowie w czasie posiedzeń przemawiali w swoim języku ojczystym. Jeżeli zależało im na odnotowaniu wystąpienia w protokole, sami musieli zadbać o tłumaczenie. Oprócz niemieckiej była zatem potrzebna literatura fachowa z pozostałych krajów monarchii, co nadwyrężało skromny budżet biblioteki. Duży przyrost księgozbioru obcojęzycznego nastąpił dopiero od 1909 roku w związku z decyzją Ministerstwa Spraw Wewnętrznych o zakupie po dwa egzemplarze dzienników ustaw w języku niemieckim oraz po jednym egzemplarzu z każdego innego języka. Natomiast ze starszych dzienników ustaw wydanych od 1 stycznia 1870 roku biblioteka miała otrzymać po jednym egzemplarzu w języku czeskim, włoskim, chorwackim, rumuńskim i słoweńskim.

Na koniec jeszcze kilka słów o Lipinerze jako człowieku, którego ciepły portret kreśli przywołany już Bruno Walter - 36 lat po śmierci przyjaciela wspomina go w swoich pamiętnikach jako niewysokiego mężczyznę o kręconych blond włosach i błyszczących niebieskich oczach, poetę obdarzonego wizją twórczą siłą oraz tą szczególną wymową i darem improwizacji, które fascynowały słuchaczy ${ }^{55}$. Szczególnie jednak wzruszająca jest relacja z okoliczności powstania ostatniego utworu Lipinera. W 1909 roku Bruno Walter spotkał przyjaciela w ciężkim stanie, jadącego na operację do kliniki (Lipiner był już wtedy ciężko chory na raka języka). Powiedział mu wówczas o przygotowywanym tomie z okazji

54 S. Lipiner, list z 2 kwietnia 1888 roku, Austriacka Biblioteka Narodowa, dostępny pod sygn. Autogr. 136/28-1 Han; por.: „und ich wäre dann wohl auch in der Lage, nach einigen Minuten mündlichen Rücksprache, auf das Eine oder Ander hingeweisen, das Ihnen speciell nützlich werden konnte. Den Schönberg kann ich oder vielmehr darf ich, nur für ganz kurze Zeit ausleihen: derartige Hand- und Nachschlagebücher müssen in der Bibliothek zur Einsicht aufliegen" (zachowano oryginalną pisownię).

${ }^{55}$ B. Walter, op.cit., s. 216. 
50. urodzin Mahlera, wyrażając ubolewanie, że go w nim zabraknie. Pięć dni później Lipiner przesłał mu wiersz pod tytułem Der Musiker spricht (Muzyk mówi), jako swój urodzinowy przyczynek, w którym zawarł odpowiedź na często niegdyś z Mahlerem poruszany problem nieśmiertelności. Po latach oddalenia wynikającego z niechęci Almy, a także częstych wojaży Mahlera stał się ten wiersz pretekstem do ponownego ich zbliżenia - Walter pisze, że udało mu się doprowadzić do spotkania Mahlera z Lipinerem $\mathrm{w}$ bibliotece parlamentu, w gabinecie Lipinera ${ }^{56}$. Po wyjściu Mahler podzielił się z nim swą radością ze spotkania po latach, a wiersz Lipinera, który uznał za "najpiękniejszy, jaki napisano”, nosił odtąd przy sobie. Obaj odeszli w 1911 roku, Mahler zmarł 18 maja, Lipiner kilka miesięcy później, 30 grudnia.

Dziś o opisywanych tu czasach świadczą wciąż jeszcze zachowane w bibliotece stylowe regały zamawiane niegdyś przez Lipinera, niemi świadkowie dawniejszych wydarzeń. Natomiast w gabinecie obecnego dyrektora, bardzo życzliwej i kompetentnej dr Elisabeth Dietrich-Schulz (od 1992 roku), której w tym miejscu należą się podziękowania za oprowadzenie po swoim "królestwie" i wskazanie pomocnych materiałów, wisi na ścianie jeszcze jedna znamienna pamiątka - rysunek ołówkiem Franza R. Kunza przedstawiający Antona von Schmerlinga, austriackiego prawnika i polityka, oraz Franciszka Jana Smolkę - tego, który niegdyś miał dobrą intuicję, by podać rękę młodemu człowiekowi z dalekiej Galicji.

\section{ALEKSANDRA WIŚNIEWSKA}

\section{From far-away Austrian Crown land of Galicia to Vienna. Siegfried Lipiner - the extraordinary librarian}

Aвstract. The present article aims to present the profile of Siegfried Lipiner (1876-1911) who was a poet, admirer of F. Nietzsche, a friend and advisor to G. Mahler, translator of works by Mickiewicz, and a brilliant librarian.

Born in Jarosław, Siegfried Lipiner moves in to Vienna in 1875 where he graduated from secondary school suma cum laude and then continued his studies at the Faculty of Philosophy. From the time of his secondary school education date his first poetical efforts, when he also managed to develop a circle of friends that included Gustav

${ }^{56}$ Ibidem, s. 219-220. 
Mahler whose work was to be later much influenced by Lipiner as his closest friend and advisor. The epic poem Der entfesselte Prometheus, published in 1876, was highly praised by Nietzsche and engaged attention of Wagner. Works written later by the author were not, however, received as warmly as his first poetical endeavours.

In 1881, thanks to the recommendation of Dr. Franciszek Smolka, the chairman of the House of Deputies of the Austrian Empire, Lipniner got a job in the library of the Imperial Council in which he worked for 30 years with commitment and devotion. Thanks to his skilful management and efforts, new funds for library were raised and new research and scientific associates, including Karl Renner - later the first post-war Chancellor and President of Austria, were co-opted. This collaboration made it possible to develop new subject catalogues, including the card catalogue that was used in the library until 1995. Lipiner's efforts succeeded in expanding the library space (that of the present-day reading room). After the 30 years of his office the library of the Council (Parliament) is regarded as one of the best of its kind.

Alongside his library work, Lipiner was engaged in further research work and professional development. In 1894 he was awarded a PhD following his doctoral dissertation Homunculus, eine Studie über Faust und die Philosophie Goethes. Inspired by Count Karol Lanckoroński, he translated works by Adam Mickiewicz: Pan Tadeusz and the Forefathers - and his translations, published in 1883 and 1887 respectively, are considered as outstanding even today.

Key words: Siegfried Lipiner (1856-1911), Adam Mickiewicz - translations, Gustav Mahler, the Library of the Parliament in Vienna. 